Annals of Plant Sciences

\title{
A note on the taxonomy of Jaeschkea microsperma (Gentianaceae)
} Mohd Shabir, Priyanka Agnihotri and Tariq Husain*

Plant Diversity, Systematics \& Herbarium, CSIR-National Botanical Research Institute, Lucknow-226001, India.

Received: 12/13/2017; Accepted: 12/25/2017

Abstract: In the present study a new combination in the genus Gentianella, G. microsperma has been proposed which has been transferred from Jaeschkea microsperma on the basis of relevant morphological characters.

Keywords: Gentianella microsperma, Gentianaceae, new combination.

\section{Introduction}

Jaeschkea Kurz, one of the smallest genus of family Gentianaceae, comprising only three species, is characterized by the position of stamens between the corolla lobes, insertion of stamens at or near the corolla sinuses and the presence of appendage scales at the base of the filaments. The genus, segregated from Gentiana L. on the basis of the position of the stamens which arise between the corolla-lobes and insertion of filaments at or near the corolla sinuses (Kurz 1870), and is closely allied to Gentianella Moench, in its habit, foliar and floral structure, but, it differs from the latter in insertion of stamens at or near the corolla sinuses, short filaments, and insertion points having appendage scales. In the present state of our knowledge, the genus is known to occur in India, Pakistan, China and Iran. All the three species, viz. J. canaliculata (Royle ex G. Don) Knobl, J. oligosperma (Griseb.) Knobl. and J. microsperma C.B. Clarke, occur in India and are found distributed in alpine zones of Jammu \& Kashmir and Himachal Pradesh in Northwest Himalaya and Sikkim in the Eastern Himalaya.

A perusal of relevant literatures viz., (Kurz 1870; Clarke 1883; Knoblauch 1894; Omer 1995; Shu 1995) however, suggests that J. microsperma, the only species of the genus reported from Eastern Himalaya, with the stamens inserted at or near the middle of the corolla and the lack of appendage scales at the base of filaments does not belong here, hence, J. microsperma is transferred to the genus Gentianella.
Gentianella microsperma (Clarke) M. Shabir \& Husain comb. nov.

Basionym: Jaeschkea microsperma Clarke, in fl. Brit India 4 (1883, p.119)

\section{Acknowledgement}

We are thankful to the Director, CSIR-National Botanical Research Institute, Lucknow for providing the necessary facilities and also Dr. D.K. Singh, retired scientist Botanical Survey of India for editing the manuscript. MS acknowledges University Grant Commission for the financial assistance to carry out the research work.

\section{References}

1. Clarke C.B. Gentianaceae. In: Hooker, J.D. (ed.), The Flora of British India. L. Reeve \& Co., London 4 (1883): 93-132.

2. Knoblauch E.F. Beitragezur Kenntniss der Gentianaceaea. Botanisches Centralblatt 60 (1894): 387

3. Kurz W.S. Gentiana jaeschkea re-established as a new genus of Gentianaceae. Asiatic Society of Bengal 39.2 (1870): 229-230.

4. Omer S. Gentianaceae In: S.I. Ali \& M. Qaiser (Eds), Flora of Pakistan. Department of Botany, University of Karachi, Karachi (1995): 1-172.

5. Shu K.Y.H. Jaeschkea In: Wu, Z.Y. \& Raven, P.H. (Eds), Flora of China (Gentianaceae through Boraginaceae), Science Press, Beijing and Missouri Botanical Garden Press, St. Louis 16 (1995): 138139.

\section{Cite this article as:}

Mohd Shabir, Priyanka Agnihotri and Tariq Husain. A note on the taxonomy of Jaeschkea microsperma (Gentianaceae). Annals of Plant Sciences 7.1 (2018) pp. 1964.

d 2 http://dx.doi.org/10.21746/aps.2018.7.1.8
*Corresponding Author:

Dr. Tariq Husain,

Plant Diversity, Systematics \& Herbarium,

CSIR-National Botanical Research Institute,

Lucknow-226001, India.

E-mail: hustar_2000@yahoo.co.uk

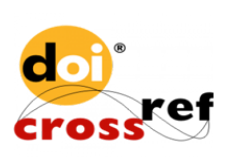

